IS THERE A DOCTOR IN THE HOUSE? 



\title{
IS THERE A DOCTOR
}

\section{IN THE HOUSE?}

\author{
Market Signals and \\ Tomorrow's Supply of Doctors
}

\section{RICHARD M. SCHEFFLER}

STANFORD GENERAL BOOKS

An imprint of Stanford University Press

Stanford, California 
Stanford University Press

Stanford, California

@2008 by the Board of Trustees of the Leland Stanford Junior University.

All rights reserved.

No part of this book may be reproduced or transmitted in any form or by any means, electronic or mechanical, including photocopying and recording, or in any information storage or retrieval system without the prior written permission of Stanford University Press.

Printed in the United States of America on acid-free, archival-quality paper

Library of Congress Cataloging-in-Publication Data

Scheffler, Richard M.

Is there a doctor in the house? : market signals and tomorrow's supply of doctors / Richard M. Scheffler.

p. cm.

Includes bibliographical references and index.

ISBN 978-0-8047-0032-0 (cloth : alk. paper)

1. Physicians--Supply and demand--United States. 2. Physicians--Supply and demand--Forecasting. 3. Managed care plans (Medical care)--United States. 4. Managed care plans (Medical care)--United States--Finance. 5. Medical care, Cost of--United States. 6. Medical education--United States--Finance. I. Title. RA410.7.S34 2008 
This book is dedicated to the incredible physicians who have taken care of me and who serve society day after day. I understand on a personal level the value of what these dedicated individuals do.

And to my seventeen-year-old son, Zach, who continually inspires me with his curiosity. I recognize that kind of eagerness to know as the lifeblood of human efforts to expand the literature in any field of inquiry. 
